\section{Boardroom diversity and audit fees: director ethnicity, independence and nationality}

\author{
Salau ABDULMALIK O., \\ Ayoib CHE AHMAD, \\ Universiti Utara Malaysia, \\ e-mail: abdmaliksalau@gmail.com
}

\section{Alsstract}

This paper investigated the effect of boardroom diversity (herein a composite measure of boardroom ethnic composition, independent and foreign directors) on audit fees in the Nigerian context. A sample of companies listed on the Nigerian stock exchange between 2010 and 2011 was used. The study found that $51 \%$ of the sampled companies were ethnically diverse, with about $21 \%$ and $49 \%$ having foreign directors and independent directors respectively. Further, the results of the panel regression revealed that boardroom diversity had a positive relationship with audit fees. The findings indicate that boardroom diversity enhances board monitoring responsibility and therefore results in an increase in demand for auditors' effort. The findings of this study have implications for future policy recommendations and formulation because they indicate that boardroom diversity could be a desirable board characteristic that can strengthen the monitoring role of the board.

Keywords: Diversity, ethnicity, foreign directors, independent directors, Nigeria.

JEL Classification: M42, A14

To cite this article:

Abdulmalik, O.S. and Che Ahmad, A. (2016), Boardroom diversity and audit fees: diectory ethnicity, independent and nationality, Audit Financiar, vol. XIV, no. 4(136)/2016, pp. 413423, DOI: 10.20869/AUDITF/2016/136/413.

Permanent link to this document:

http://dx.doi.org/10.20869/AUDITF/2016/136/413. 


\section{Introduction}

The board of directors is supposedly a collection of individuals with heterogeneous competencies and capabilities pooled together to perform monitoring and advisory functions in a company (Walt and Ingley, 2003). Accordingly, the issue of what constitutes the correct mix of individuals and how these individuals improve board outcomes is of regulatory concern. The aftermath of each and every corporate governance failure has caused regulators to look inward and to see how boardroom composition and functions could be reformed to provide an effective oversight function (Ararat, Aksu and Cetin, 2015; Gul, Srinidhi and Tsui, 2008). This is critical most especially in countries where external monitoring mechanisms are practically non-existent and investors and regulators look forward to the monitoring role of the board of directors (Dahya, Dimitrov and McConnell, 2008). Most corporate governance regulatory requirements have laid emphasis on boardroom composition and demands for diversity in skills, knowledge and social representativeness of boardroom members.

The theoretical justification behind such requirements is found in both the agency theory and the resources dependency theory. The agency theory underscores the importance of boardroom diversity in ensuring an effective and independent board monitoring function. Meanwhile, the resource dependency theory establishes the significant role played by the board of directors in connecting a firm with the external resources needed for its survival; hence, the need exists for boardroom structures to be a reflection of the society in which it operates (Walt and Ingley, 2003). As it can be deduced from the two theories, boardroom diversity could improve board processes and outcomes. This is because individuals have distinct intellectual and social traits that are best harnessed when correctly pooled together. Diversity can be seen as the pool of differences among board members with respect to individual inherent traits and characteristics (Kearney, Gebert and Voelpel, 2009). Consistent with the agency theory postulation, this current study aims to investigate the relationship between boardroom diversity and the intensity of demand for audit service through the amount paid as audit fees in Nigeria.

As noted in Simunic's (1980) audit production function, audit charges reflect the expected efforts expended during an audit engagement and auditor risk exposure. While research on audit fees is abundant, further investigation on their relationships with boardroom diversity has, to the best of our knowledge, yet to receive sufficient empirical attention, most especially in the context of Nigeria.

Nigeria is an interesting setting in which to study board diversity in the context of an emerging market because Nigerian society is culturally diverse. Nigeria, society comprises more than 200 ethnic groups divided along three prominent groups, namely, Hausa, Yoruba and Igbos. This composition is differently configured than countries like Malaysia in which similar studies have been conducted. For example, Malaysian law recognizes two groups: Bumiputera and nonBumiputera. Those who are Bumiputera are known as "sons of the soil", and the Bumiputera ethnic group (Malays) are economically and politically favoured over the non-Bumiputera ethnic group, which comprises the Chinese and Indians. Conversely, the three ethnic groups in Nigeria have equal rights and claims to the political and economic resources of the country, hence no ethnic group is favoured.

Therefore, boardroom heterogeneity with respect to ethnicity to reflect the cultural dynamics in Nigeria society is imperative to promote effectiveness in companies (Adegbite, 2015). As noted one interviewee in Adegbite's study of corporate governance, "boards with sufficient tribal diversity are considered to have better governance systems and will further have a sense of belonging and identity throughout the country" (Adegbite, 2015, p. 16). This observation suggests that the presence of members of the three ethnic groups on a board might contribute positively to corporate performance with respect to a wealth of experiences and networking. It would be interesting as well to see how the presence of these three ethnic groups affects audit quality. In addition, corporate governance practice as a "distinct concept" is of recent origin in Nigeria (Ofo, 2013) and is still evolving. Several recent regulatory reforms on corporate governance in Nigeria have included:

- the 2003 Code of Corporate Governance in Nigeria (SEC Code);

- the 2006 mandatory Code of Corporate Governance for Nigerian Banks post consolidation (CBN Code); 
- the 2007 Code of Conduct for Shareholder Associations in Nigeria; and

- the National Code of Corporate Governance, which is currently being developed.

The Companies and Allied Matters Act, Cap. C20, Laws of the Federation of Nigeria 2004 had elaborate provisions on the appointment, removal, duties, and liabilities of corporate directors but had no provisions for types of directors (Proshare News, 2013). Therefore, boardroom structural diversity is still feeble due to insufficient capacities and the lack of independent directors on boards (Adegbite, 2015).

Moreover, corporate ownership has passed through various regulatory reforms among which are the 1962 Foreign Exchange Control Act, 1972 Indigenity Policy, and the 1988 Privatization and Commercial Policy (Ahunwan, 2002). All these policies have implications for corporate governance practices. Similarly, findings of previous studies show that the traditional role and overbearing influence of family ownership has impacts on board process (see also Klein, Shapiro and Young, 2004; MacAvoy and Millstein, 2003). Accordingly, agency challenges emerging from the ownership structure in Nigeria compared with other Englishspeaking countries tend to expropriate minority interests (Adegbite and Nakajima, 2011).

Therefore, investigating how a composite measure of boardroom diversity cushions the effect of the agency problem in Nigeria context is interesting. Using a sample of firms from 2010 to 2011, evidence is provided supporting the theoretical preposition that board diversity enhances the board's monitoring role as it creates room for more independence in the boardroom. Specifically, we show that the extent of boardroom diversity is associated with the demand for more audit effort expressed by audit fees. Similarly, we test individual diversity proxies, and our findings reveal that all the three proxies exhibit a positive relationship, however only with the proportion of foreign directors in the boardroom. Our findings provide insights to regulators and investors on how corporate structure and operating results affect audit pricing. Therefore, the study extends and contributes to the body of knowledge in corporate governance and audit fee literature by using data from a less regulated environment.

The remainder of this paper is organised as follows. Section 1 provides a literature review and the hypothesis for the study. Data and method of sampling are discussed in Section 2, and the research design/methodology in Section 3. The results and the analysis are discussed in Section 4. Finally, Section 5 includes a summary of our findings, implications and limitations of our findings, and suggestions for future studies.

\section{Literature review and hypotheses development}

Numerous studies have examined the relationships between board characteristics and board process outcomes such as firm performance (Amran and Ahmad, 2010; Ramdani and Witteloostuijn, 2010), value relevance of earnings (Carter, Simkins, and Simpson, 2003), and earnings quality and the intensity of demand for audit service via audit pricing (Carcello, Hermanson, Neal and Riley, 2002; Ahmad, Houghton and Yusof, 2006; Ahmad and Mansor, 2009). Extant studies on audit pricing starting from the seminal work of Simunic (1980) have pointed out client-related factors such as auditee size, auditee complexity, and auditee riskiness as important variables that influence the amount paid as audit fees in different regulatory and institutional contexts. Examples of such studies include Carcello et al. (2002), Abbott et al. (2003) and Boo and Sharma (2008) in the United States, Vafeas and Waegelein (2007) and Zaman, Hudaib and Haniffa (2011) in the United Kingdom, and Goodwin-Stewart and Kent (2006) and Stewart and Munro (2007) in Australia.

Further, other studies on the intensity of audit demand have established a relationship between board characteristics and audit pricing. The argument has been made that an independent and diligent board will demand a high quality audit service due to the incentive to protect board reputational capital, reduce board litigation risks and safeguard shareholder interests (Fama and Jensen, 1983; Gilson, 1990). The theoretical justification underlying this relationship is in line with Fama and Jensen's (1983) argument that independent directors have the incentive to monitor management due to their reputation; hence, independent directors are effective in disciplining management. Consistent with Fama and Jensen's (1983) theoretical postulation, Armstrong, Core and Guay (2014) reported that firms with a high number of independent directors are more transparent. Goodwin-Stewart and Kent (2006) found 
that an audit committee with independent characteristics increase audit effort and audit fees. In their study, Mitra, Hossain and Deis (2007) documented a positive relationship between bulk institutional stock ownership and audit fees, while Carcello et al. (2002) reported that independent directors demand high quality audits as reflected in the amount paid as audit fees by an auditee.

Lately, academic researchers have recognized the influence of resource-rich composed boards of directors in providing critical resources needed by their firms (Hillman, Withers and Collins, 2009). The resource dependency theory acknowledges the interdependency between an organization and its environment (Pfeffer, 1972). In order to succeed, managers act in manners that minimize such dependencies when they constitute a threat or gain from them when they create opportunities.

Hence, the presence of foreigners on the corporate board could be argued as enhancing board competency by virtue of their foreign exposure in terms of skills, knowledge, values, norms, and understanding (Ruigrok, Peck and Tacheva, 2007). Ruigrok, Peck and Tacheva (2007) posited that foreign directors are not connected with closed domestic networks and are independent from management. Their presence on the board signals to investors, most especially minority foreign investors, that the firm is professionally managed and their rights are safeguarded (Oxelheim and Randøy, 2002). Consequently, the presence of foreigners on the board might necessitate the demand for a high quality audit. As mentioned earlier, foreign directors tend to have different exposure to governance practices and are bound to import their foreign ideas into the way local companies are managed. This makes the board demand for an expanded audit scope grow in order to protect their reputational capital.

Similarly, from another perspective, several studies have investigated the influence of gender and ethnicity of directors on audit outcome. Studies on gender and ethnicity diversity have noted variations in individual traits dictated by gender and ethnic groups of individuals, which can affect decision-making process in the organisation. For instance, by their nature, females have been observed to be more risk averse and more independent-minded compared to their male counterparts. Accordingly, females exhibit a high level of monitoring intensity. Gul, Srinidhi and Tsui (2008) examined the association between female directors (proxy for board diversity) and audit fees, using a sample of firms in the United States from 2001 to 2003.

The authors reported that boards with a higher proportion of female directors in the boardroom demand more in terms of audits; thus, high audit fees are consistent with the agency theory.

Other studies like those of Yatim, Kent and Clarkson (2006) and Johl, Subramaniam and Zain (2006) of Malaysia have observed board ethnic diversity effects on audit fees and all provided supporting evidence that the ethnic composition of the board impacts audit fees. Watson, Kumar and Michaelsen (1993) argued that culturally diverse group are assets through which group process and solutions to problem are achieved. To strengthen the argument, Baer, Niessen-Ruenzi and Ruenzi (2007), based on the information and decisionmaking theory, argued that team members are part of a different network and this enhances group knowledge and skills. Implicitly, team members have information from different sources, which helps to improve their performance. However, the social diversity theory maintained that ethnic diversity among team members could generate conflicts due to information asymmetry, lower satisfaction, and low commitment among members. Ahmad, Houghton and Yusof (2006) investigated the extent to which board ethnic associations affect the market for audit services in Malaysia. The authors established a significant relationship between ethnic associations of the board of directors and the choice of auditor.

Apart from the fact that the above studies were conducted in developed countries, empirical findings from these studies have been inconsistent (Felix, Gramling and Maletta, 2001; Godwin-Stewart and Kent, 2006; Vafeas and Waegelein, 2007). Although quite a number of studies examined board structure diversity (independent directors) and demographic diversity (director's ethnicity, nationality and gender diversity), these studies only used a single proxy and the findings of the studies mostly cannot be generalized or extended to other contexts. In addition, investigations of performance outcomes of single demographic and structural diversity attributes, respectively, are equivocal (Ararat, Aksu and Cetin, 2015).

Therefore, the current paper extends this area of research by developing a composite index of board diversity measure using Blau's (1977) measure of variety and investigating its effects on the intensity of audit demand in Nigeria. Board diversity is 
operationalized by combining different diversity indicators compared to the single constructs used in prior studies. We argue that much insight into the studied phenomenon could be gained by integrating these different diversity indicators. In furtherance of the above conjectures, this study posits that:

H: Boardroom diversity (herein operationalised by combining difference diversity indicators) will lead to a higher demand for audit effort and a corresponding increase in audit fees.

\section{Data and method of sampling}

The sample includes all public listed firms on the Nigerian Stock Exchange with annual reports available online. Poor record keeping and the absence of data banks have bedevilled accounting research in Nigeria. Most often older copies of annual reports were burnt to create space for new ones. Records were found for of 213 and 218 listed companies in 2010 and 2011 respectively, but after excluding all financial institutions, the researchers were left with 123 annual report observations for firms. This included 65 annual reports for 2010 and 58 annual reports for 2011. The sampling process is shown in Table 1. The mandatory changes in reporting and auditing requirements at the end of 2010 informed the choice of the study period. First, the new corporate governance code issued by the Nigeria Security and Exchange Commission in 2011 was supposed to be voluntarily adopted by all listed companies by April 2011. In addition, the federal reporting council vested with the responsibility of ensuring transparency and appropriate disclosure practices, was established in 2011 too. Second, all listed companies were to adopt the International Financial Reporting Standards by the end of 2012 and 2011 precedes the year of adoption.

\begin{tabular}{|l|r|r|r|r|r|}
\hline \multicolumn{2}{|l|}{ Table 1. Sample collection procedure } \\
\hline Year & $\begin{array}{l}\text { Total listed } \\
\text { companies }\end{array}$ & \multicolumn{2}{c|}{$\begin{array}{c}\text { Banks and other } \\
\text { financial institutions }\end{array}$} & $\begin{array}{c}\text { Not available } \\
\text { online and NSE }\end{array}$ & $\begin{array}{c}\text { Final } \\
\text { sample }\end{array}$ \\
\hline $\mathbf{2 0 1 0}$ & 213 & 81 & 67 & 65 \\
\hline $\mathbf{2 0 1 1}$ & 218 & 71 & 89 & 58 \\
\hline Sum & 431 & 152 & 156 & 123 \\
\hline
\end{tabular}

Source: Authors' compilation, 2016

\section{Research design and variable measurements}

Based on the theoretical framework and the hypothesis that was developed, the conceptual model of auditing pricing introduced by Simunic (1980) as extended by
Chan, Ezzamel and Gwilliam (1993) and Boo and Sharma (2008) was adopted in this study. A panel data regression model was used to examine the relationship between boardroom diversity and audit fees along with firm specific variables to control for company size, complexity and audit risk.

$$
\begin{aligned}
& \mathrm{FEE}=\alpha_{i t}+\beta_{1} \mathrm{TBD}_{i t}+\beta_{2} \mathrm{FOR}_{i t}+\beta_{8} \mathrm{ETHNIC}_{i t}+\beta_{4} \mathrm{INDP}_{i t}
\end{aligned}
$$

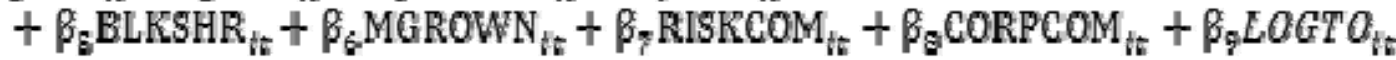

$$
\begin{aligned}
& +\beta_{10} \text { RITA }_{t t}+\beta_{11} \text { GEARING }_{i t}+\beta_{12} \text { BIG }_{i t}+\beta_{18} \text { NOSUB }_{i t}+\varepsilon_{i t}+\mu_{i t}
\end{aligned}
$$




\section{Table 2. Variable description}

\begin{tabular}{|l|l|}
\hline \multicolumn{1}{|c|}{ Variable } & \multicolumn{1}{c|}{ Description } \\
\hline FEE & Natural logarithms of audit fees. \\
\hline TBD & Composite measure of board dynamics. \\
\hline FOR & The number of foreign directors in boardroom divided by board size. \\
\hline ETHNIC & A dummy variable set to 1 for companies whose board is made up of the three ethnic groups and 0 if otherwise. \\
\hline INDP & Percentage of independent directors on the board. \\
\hline BLKSHR & The percentage of shares held by individual investors above 5 percent. \\
\hline MGROWN & Percentage of shares held by directors \\
\hline RISKCOM & A dummy variable set to 1 for companies that establish risk management committee. \\
\hline CORPCOM & A dummy variable set to 1 for companies that establish corporate governance committee. \\
\hline LOGTO & Natural logarithms of total assets. \\
\hline RITA & Ratio of inventory to total assets. \\
\hline GEARING & Long term debt divided by total assets \\
\hline BIG4 & A dummy variable set to 1 for companies audited by any of the Big4 audit firm and 0 if otherwise. \\
\hline NOSUB & Number of subsidiaries plus one. \\
\hline$\mu_{\mathrm{i}}$ it & Error term. \\
\hline
\end{tabular}

Source: Authors' compilation, 2016

\section{Resulits of the analysis}

\subsection{Preliminary analysis}

Table 3 shows the descriptive statistics for the full sample of 123 observations for the firms that were employed to run the audit fees model. The table presents the mean, minimum, maximum, and standard deviation values. As shown in Table 3, the audit fees for the sampled companies ranged between 400,000 Naira and 135,000,000 Naira (foreign exchange rate is 165 Naira for 1 dollar), and foreign-owned companies represented by FOR had a mean value of $0.21 \%$, the mean value for boardroom ETHNIC representation was $0.51 \%$ and INDP mean value was $0.49 \%$. The value for individual concentrated ownership (BLKSHR) ranged between $0.05 \%$ and $0.99 \%$ and the maximum value of managerial ownership (MGROWN) was 3.79\%. The results also showed that RISKCOM and CORPCOM had mean values of $36 \%$ and $28 \%$ respectively, indicating that less than half of the sampled companies had established a risk management committee and a corporate governance committee. The mean number of foreign directors on the board was $21 \%$.

\begin{tabular}{|c|c|c|c|c|c|}
\hline Variable & Observations & Mean & Standard deviation & Minim & Maxim \\
\hline FEE & 123 & $14,600,000$ & $20,400,000$ & 400,000 & $135,000,000$ \\
\hline TBD & 123 & 0.47 & 0.31 & 0.0 & 1.18 \\
\hline FOR & 123 & 0.21 & 0.24 & 0 & 0.89 \\
\hline ETHNIC & 123 & 0.51 & 0.50 & 0 & 1 \\
\hline INDP & 123 & 0.49 & 0.28 & 0 & 1 \\
\hline BLKSHR & 123 & 0.56 & 0.21 & 0.05 & 0.99 \\
\hline MGROWN & 123 & 0.14 & 0.38 & 0 & 3.79 \\
\hline RISKCOM & 123 & 0.36 & 0.48 & 0 & 1 \\
\hline CORPCOM & 123 & 0.28 & 0.45 & 0 & 1 \\
\hline LOGTO & 123 & 9.73 & 0.81 & 7.51 & 11.38 \\
\hline RITA & 123 & 0.89 & 4.88 & 0 & 54.14 \\
\hline GEARING & 123 & 10.76 & 18.52 & 0 & 122.37 \\
\hline BIG4 & 123 & 0.62 & 0.49 & 0 & 1 \\
\hline NOSUB & 123 & 2.93 & 2.92 & 0 & 14 \\
\hline
\end{tabular}

Source: Authors' compilation, 2016 


\subsection{Tests for random and fixed effects regression}

The choice between random and fixed effects was based on the Hausman test (Green, 1997). In order to choose the appropriate model, the Hausman test was run because the Hausman test checks whether the errors $\left(U_{i}\right)$ are correlated with the regressors. If pro $>$ chi2 is $<0.05$ (i.e., significant) the fixed effect model is used (Greene, 1997). The Hausman test shows a probability greater than 0.05 , so the null hypothesis was rejected; hence, the random effects model is appropriate for the study. By implication, the individual error component is not correlated with the regression variabiles, thus OLS estimator is consistent.

\subsection{Results of model}

Table 4 presents the generalist square random regression results. A good linear fit was achieved with an adjusted $R^{2}$ of $64 \%$. This suggests that the model explains more than of the $60 \%$ variation between the dependent variable and the independent variable. The regression coefficient for the composite measure of board dynamics (TBD) in model 1 was positive and significant in predicting the amount paid as audit fees by Nigerian publicly listed companies. The finding is consistent with the agency theory, which states that an effective board will be more thorough in their monitoring role and therefore will make more demands in an audit engagement. Next, the regression coefficient for nationality of members of the board of director (FOR) in model 2 was positive and significant indicating that in order to be more transparent, foreign directors will pay more for audit services to ensure the credibility of financial statements and protect the reputations of the directors (Ahmad, Houghton and Yusof, 2006). In model three, the coefficient of boardroom ethnic balance (ETHNIC), which indicates the presence of the three prominent ethic groups in Nigeria in the boardroom, the coefficient was positive although not significant. Lastly, in model 4, the coefficient for the percentage of independent directors (INDP) was positive but not significant.

\begin{tabular}{|c|c|c|c|c|c|}
\hline & MODEL 1 & MODEL 2 & MODEL 3 & MODEL 4 & VIF \\
\hline TBD & $\begin{array}{c}0.049 \\
\left(2.84^{* * *}\right)\end{array}$ & & 0.033 & 0.021 & 7.47 \\
\hline FOR & & $\begin{array}{c}0.524 \\
\left(4.15^{\star \star *}\right)\end{array}$ & & & 2.26 \\
\hline ETHNIC & & & $\begin{array}{l}0.033 \\
(1.35)\end{array}$ & & 6.28 \\
\hline INDP & & & & $\begin{array}{l}0.021 \\
(0.47)\end{array}$ & \\
\hline BLKSHR & $\begin{array}{c}0.074 \\
\left(2.61^{* * *}\right)\end{array}$ & $\begin{array}{c}0.053 \\
(1.530)\end{array}$ & $\begin{array}{c}0.069 \\
\left(2.44^{* * *}\right)\end{array}$ & $\begin{array}{c}0.074 \\
\left(2.53^{\star \star \star}\right)\end{array}$ & 1.23 \\
\hline MGROWN & $\begin{array}{c}-0.081 \\
\left(-3.61^{* * *}\right)\end{array}$ & $\begin{array}{c}-0.113 \\
\left(-5.53^{* * *}\right)\end{array}$ & $\begin{array}{c}-0.076 \\
\left(-3.4^{* * \star}\right)\end{array}$ & $\begin{array}{c}-0.075 \\
\left(-3.34^{* \star *}\right)\end{array}$ & 1.29 \\
\hline RISKCOM & $\begin{array}{c}-0.095 \\
\left(-8.33^{* * *}\right)\end{array}$ & $\begin{array}{c}-0.088 \\
\left(-5.78^{* * *}\right)\end{array}$ & $\begin{array}{c}-0.089 \\
\left(-6.9^{\star \star \star}\right)\end{array}$ & $\begin{array}{c}-0.099 \\
\left(-8.08^{* * *}\right)\end{array}$ & 1.47 \\
\hline CORPCOM & $\begin{array}{c}0.088 \\
\left(6.29^{* * *}\right)\end{array}$ & $\begin{array}{c}0.099 \\
\left(6.41^{\star \star \star}\right)\end{array}$ & $\begin{array}{c}0.082 \\
\left(6.01^{* \star *}\right)\end{array}$ & $\begin{array}{c}0.086 \\
\left(6.25^{* * *}\right)\end{array}$ & 1.35 \\
\hline LOGTO & $\begin{array}{c}0.417 \\
\left(3781^{* * *}\right)\end{array}$ & $\begin{array}{c}0.399 \\
\left(26.08^{* * *}\right)\end{array}$ & $\begin{array}{c}0.415 \\
\left(40.11^{* * *}\right)\end{array}$ & $\begin{array}{c}0.418 \\
\left(39.42^{* * *}\right)\end{array}$ & 1.68 \\
\hline NOSUB & $\begin{array}{c}0.020 \\
\left(6.16^{* * *}\right)\end{array}$ & $\frac{10.026}{\left(7.58^{* * *}\right)}$ & $\begin{array}{c}0.019 \\
\left(5.58^{* * *}\right)\end{array}$ & $\begin{array}{c}0.021 \\
\left(5.95^{\star * \star}\right)\end{array}$ & 1.39 \\
\hline RITA & $\begin{array}{c}-0.098 \\
\left(-7.72^{* * *}\right)\end{array}$ & $\begin{array}{c}-0.135 \\
\left(-5.91^{* * *}\right)\end{array}$ & $\begin{array}{l}-0.087 \\
\left(-7.2^{* * \star}\right)\end{array}$ & $\begin{array}{c}-0.085 \\
\left(-0.085^{* \star *}\right)\end{array}$ & 1.19 \\
\hline GEARING & $\begin{array}{c}-0.001 \\
\left(-4.08^{\star * \star}\right)\end{array}$ & $\begin{array}{l}-0.001 \\
(-1.52)\end{array}$ & $\begin{array}{c}-0.001 \\
\left(-4.13^{\star * \star}\right)\end{array}$ & $\begin{array}{c}-0.001 \\
\left(-3.04^{\star * \star}\right)\end{array}$ & 1.09 \\
\hline BIG4 & $\begin{array}{c}0.277 \\
\left(19.9^{* * *}\right)\end{array}$ & $\begin{array}{c}0.270 \\
\left(14.02^{* \star *}\right)\end{array}$ & $\begin{array}{c}0.284 \\
\left(22.33^{* \star *}\right)\end{array}$ & $\begin{array}{c}0.282 \\
\left(20^{* * *}\right)\end{array}$ & 1.18 \\
\hline _cons & $\begin{array}{c}2.629 \\
\left(27.65^{\star \star \star}\right)\end{array}$ & $\begin{array}{c}2.808 \\
\left(20.82^{\star \star \star}\right)\end{array}$ & $\begin{array}{c}2.653 \\
\left(29.27^{\star \star \star}\right)\end{array}$ & $\begin{array}{c}2.629 \\
\left(27.18^{\star \star \star}\right)\end{array}$ & \\
\hline$F$ & 0.000 & 0.000 & 0.000 & 0.000 & \\
\hline Mean Vif & & & & & 2.32 \\
\hline Adjusted Rs & 64 & 60 & 60 & 60 & \\
\hline
\end{tabular}

Notes: ${ }^{*}=$ significant at $10 \%,{ }^{* *}=$ significant at $5 \%$ and ${ }^{* * *}=$ significant at $1 \%$

Source: Authors' compilation, 2016 
Across the three models the coefficient of individual block shareholders (BLKSHR) was positive and significant, although in model 2 the coefficient was not significant. The coefficient of managerial ownership was significant and negative across the three models. With respect to board risk committee (RISKCOM), the coefficient was negative and significant in the three models, and, for the corporate governance committee (CORPCOM), the coefficient was positive and significant in all the three models. In addition, and consistent with prior literature, firm-specific control variables such as client size proxy by log of turnover (LOGTO), client complexity proxy by number of subsidiaries (SUB) and the ratio of inventory to total assets (RITA) and client risk proxy by long term debt to total assets (GEARING) were all significant and in line with the findings of prior studies. Likewise, the coefficient of the proxy for Big4 auditors for auditor characteristics (BIG4) was positive and significant in all the three models.

\section{Conclusion}

Factors determining auditors' fees have been of great interest owning to the likely threat of high fees to auditors' independence. Similarly, boardroom diversity is widely being touted with the claim that it improves the oversight function of the board of directors. To examine such issues in the context of Nigeria, this study looked at the effect of boardroom diversity on audit demand expressed by audit fees. Overall, the paper contributes to the investigation on the diversity-audit demand relationship by showing that multiple diversity attributes have a compound effect on the extent of audit demand. The results found that the total board diversity (TBD) index developed in this study impacted the demand of the board of directors for audit services more significantly than the individual diversity attributes as TBD enhanced audit demand. This finding is consistent with theoretical justification that boardroom diversity improves the monitoring function of the board of directors because the board will likely comprise individuals with independent minds (Walt and Ingley, 2003). According to Carcello et al. (2002) and Knechel and Willekens (2006), independent and diligent board of directors will demand high-quality audit services to safeguard their reputations and avoid litigation risks arising from non-performance.
The current study's finding reflecting the Nigeria context may provide more relevant and interesting conclusions for emerging markets that exhibit similar corporate governance features most especially in countries with type two agency problems and with weak implementation and enforcement mechanisms. Based on this study, regulators could consider improving boardroom diversity, most especially with respect to the individual diversity features examined, would be an excellent measure to improve the effectiveness of boards of directors in Nigeria.

Like any other empirical study of this nature, this research is imperfect and has limitations requiring that the findings be interpreted within the purview of the highlighted limitations. The first limitation arises from the limited generalizability of the study. This is due to the small sample size and single country context that was necessitated due to the hand collection of data, the availability of data at the time of data collection and the need to control for institution differences in the sample. In addition, the present study excludes banks and other financial institutions due to their reporting structures. To this extent, the results of the sample may suffer from sample bias. Although the sample is a replica of many other emerging markets, future studies could use longitudinal data and adapt the model used in this current study to provide more robust findings.

Second, contextual variables capturing corporate governance practices in Nigeria that are distinct from what are obtainable anywhere else should be introduced in future studies on audit pricing in Nigeria. Probably, such variables could serve to explain the variations in audit fees better within the Nigerian context. Such variables could emanate from ownership structure types in the country or the dominance of one ethnic group in the board structure, if possible, in line with the risk averseness and business shrewdness of each ethnic group. Similarly, future studies could capture the overall effects of regulatory changes in the Nigerian financial reporting architecture and investigate how these affect the audit market as a whole.

Third, non-audit fees are lumped together with audit fees in the annual reports and consequently the study used auditor's remuneration. However, the study does not expect non-separate disclosure of these fees to affect the findings of the study because it is less relevant in Nigeria. 
Lastly, consistent with resource dependency theory, future studies within this regulatory setting could examine the impact of networking of politically connected firms and board negotiation skills on audit pricing.

\section{REFERENCES}

1. Abbott, L.J., Parker, S., Peters, G.F. and Raghunandan, K. (2003), The association between audit committee characteristics and audit fees, Auditing: A Journal of Practice \& Theory, vol. 22, no. 2, pp.17-32, DOl: http://dx.doi.org/10.2308/ aud.2003.22.2.17.

2. Adegbite, E. (2015), Good corporate governance in Nigeria: Antecedents, propositions and peculiarities, International Business Review, vol. 24, no. 2, pp. 319-330, DOl: http://dx.doi.org/10. 1016/j.ibusrev.2014.08.004.

3. Adegbite, E. and Nakajima, C. (2011), Corporate governance and responsibility in Nigeria. International Journal of Disclosure and Governance, vol. 8, no. 3, pp. 252-271, DOI: http://dx.doi.org/10.1057/jdg.2011.2.

4. Ahmad, A.C. and Mansor, N. (2009), Board independence, ownership structure, audit quality and income smoothing activities: A study on Malaysian market, Journal of Modern Accounting and Auditing, vol. 5, no. 11, pp. 1-13.

5. Ahmad, A.C., Houghton, K.A. and Yusof, N.Z.M. (2006), The Malaysian market for audit services: Ethnicity, multinational companies and auditor choice, Managerial Auditing Journal, vol. 21, no. 7, pp. 702-723, DOI: http://dx.doi.org/10.1108/ 02686900610680503.

6. Ahunwan, B. (2002), Corporate governance in Nigeria, Journal of Business Ethics, vol. 37, no. 3 , pp. 269-287, Stable URL: http://www.jstor.org/ stable/25074754.

7. Amran, N.A. and Ahmad, A.C. (2010), Corporate governance mechanisms and performance: Analysis of Malaysian family and non-family controlled companies, Journal of Modern Accounting and Auditing, vol. 6, no. 2, pp. 2-15.

8. Ararat, M., Aksu, M. and Tansel Cetin, A. (2015), How board diversity affects firm performance in emerging markets: Evidence on channels in controlled firms, Corporate Governance: An
International Review, vol. 23, no. 2, pp. 83-103, DOI: http://dx.doi.org/10.1111/corg.12103.

9. Armstrong, C. S., Core, J. E. and Guay, W. R. (2014), Do independent directors cause improvements in firm transparency?, Journal of Financial Economics, vol. 113, no. 3, pp. 383-403, DOI: http://dx.doi.org/10.1016/j.jfineco.

2014.05.009.

10. Baer, M., Niessen-Ruenzi, A. and Ruenzi, S. (2007), The impact of work group diversity on performance: Large sample evidence from the mutual fund industry, CFR Working Paper No. 0716, University of Cologne. [pdf] Available at: http://hdl.handle.net/10419/57751 [Accessed March 9, 2016]

11. Blau, P.M. (1977), Inequality and heterogeneity: A primitive theory of social structure, vol. 7, New York: Free Press.

12. Boo, E.F. and Sharma, D. (2008), Effect of regulatory oversight on the association between internal governance characteristics and audit fees, Accounting and Finance, vol. 48, no. 1, pp. 51-71, DOI: http://dx.doi.org/10.1111/j.1467629X.2007.00229.x.

13. Carcello, J.V., Hermanson, D.R., Neal, T.L. and Riley Jr., R.A. (2002), Board characteristics and audit fees, Contemporary Accounting Research, vol. 19, no. 3, pp. 365-384, DOI: http://dx.doi.org/ 10.1506/CHWK-GMQ0-MLKE-K03V.

14. Carter, D.A., Simkins, B.J. and Simpson, W.G. (2003), Corporate governance, board diversity, and firm value, Financial Review, vol. 38, no. 1, pp. 3353, DOl: http://dx.doi.org/10.2139/ssrn.304499.

15. Chan, P., Ezzamel, M. and Gwilliam, D. (1993), Determinants of audit fees for quoted UK companies, Journal of Business Finance and Accounting, vol. 20, no. 6, pp. 765-786, DOl: http://dx.doi.org/10.1111/j.14685957.1993.tb00292.x. 
16. Dahya, J., Dimitrov, O. and McConnell, J.J. (2008), Dominant shareholders, corporate boards, and corporate value: A cross-country analysis, Journal of Financial Economics, vol. 87, no. 1, pp. 73-100, DOI: http://dx.doi.org/10.1016/j.jfineco. 2006.10.005.

17. Fama, E.F. and Jensen, M.C. (1983), Separation of ownership and control, The Journal of Law and Economics, vol. 26, no. 2, pp. 301-325, Stable URL: http://www.jstor.org/stable/725104.

18. Felix, W., Gramling, A. and Maletta, M. (2001), Determinants of external audit fees: The importance of a client's internal audit department, Journal of Accounting Research, vol. 39, no. 3, pp. 513-534.

19. Gilson, S.C. (1990), Bankruptcy, boards, banks, and blockholders: Evidence on changes in corporate ownership and control when firms default, Journal of Financial Economics, vol. 27 , no. 2, pp. 355-387, DOI: http://dx.doi.org/10.1016/ 0304-405X(90)90060-D.

20. Goodwin-Stewart, J. and Kent, P. (2006), Relation between external audit fees, audit committee characteristics and internal audit, Accounting and Finance, vol. 46, no. 3, pp. 387-404, DOl: http://dx.doi.org/10.1111/j.1467629X.2006.00174.x.

21. Greene, W.H. (1997), Econometric analysis, Upper Saddle River, New Jersey: Prentice Hall.

22. Gul, F.A., Srinidhi, B. and Tsui, J.S. 2008. Board diversity and the demand for higher audit effort, [pdf], Available at SSRN 1359450, DOI: http://dx.doi.org/10.2139/ssrn.1359450.

23. Hillman, A.J., Withers, M.C. and Collins, B.J. (2009), Resource dependence theory: A review, Journal of Management, vol. 35, no. 6, pp. 14041427, DOI: http://dx.doi.org/10.1177/ 0149206309343469.

24. Johl, S., Subramaniam, N. and Zain, M.M. (2012), Audit committee and CEO ethnicity and audit fees: some Malaysian evidence, The International Journal of Accounting, vol. 47, no. 3, 302-332, doi: http://dx.doi.org/10.1016/j.intacc.2012.07.002.

25. Kearney, E., Gebert, D. and Voelpel, S.C. (2009), When and how diversity benefits teams: The importance of team members' need for cognition,
Academy of Management Journal, vol. 52, no. 3, pp. 581-598, DOl: http://dx.doi.org/10.5465/ AMJ.2009.41331431.

26. Klein, P., Shapiro, D. and Young, J. (2004), Board independence and the family-owned firm, Canadian Investment Review, vol. 17, no. 3, pp. 8-16.

27. Knechel, W.R. and Willekens, M. (2006), The role of risk management and governance in determining audit demand, Journal of Business Finance and Accounting, vol. 33, no. 9-10, pp. 1344-1367, DOI: http://dx.doi.org/10.1111/j. 1468-5957.2006.01238.x.

28. Mitra, S., Hossain, M. and Deis, D.R. (2007), The empirical relationship between ownership characteristics and audit fees, Review of Quantitative Finance and Accounting, vol. 28, no. 3, pp. 257-85, DOI: http://dx.doi.org/ 10.1007/s11156-006-0014-7.

29. MacAvoy, P.W. and Millstein, I. (2003), The Emergence and the Development of the Governance Problem. In The Recurrent Crisis in Corporate Governance. Stanford, CA: Stanford University Press.

30. Ofo, N. (2013), Criteria for determining the independent status of independent directors in Nigeria: A critical evaluation, International Company and Commercial Law Review, pp. 382393. [pdf]. Available at SSRN: http://ssrn.com/ abstract $=2045545$ [Accessed on March 9, 2016].

31. Oxelheim, L. and Randøy, T. (2003), The impact of foreign board membership on firm value, Journal of Banking and Finance, vol. 27, no. 12, pp. 23692392, DOI: http://dx.doi.org/10.1016/S03784266(02)00395-3.

32. Pfeffer, J. (1972), Size and composition of corporate boards of directors: The organization and its environment, Administrative Science Quarterly, vol. 17, no. 2, pp. 218-228, Stable URL: http://www.jstor.org/stable/2393956.

33. Proshare News (2013), Flow of Foreign Portfolio Investments on the Nigerian Stock Market [online], Available at: http://www.proshareng.com/news/ 19093 [Accessed on March 9, 2016].

34. Ramdani, D. and Witteloostuijn, A. V. (2010), The impact of board independence and CEO duality on 
firm performance: A quantile regression analysis for Indonesia, Malaysia, South Korea and Thailand, British Journal of Management, vol. 21, no. 3, pp. 607-627, DOI: http://dx.doi.org/10.1111/j.14678551.2010.00708.x.

35. Ruigrok, W., Peck, S. and Tacheva, S. (2007), Nationality and gender diversity on Swiss corporate boards, Corporate Governance: An International Review, vol. 15, no. 4, pp. 546-557, DOl: http://dx. doi.org/10.1111/j.1467-8683.2007.00587.x.

36. Simunic, D.A. (1980), The pricing of audit services: Theory and evidence, Journal of Accounting Research, vol. 18, no. 1, pp. 161-190, Stable URL: http://www.jstor.org/stable/2490397.

37. Stewart, J. and Munro, L. (2007), The impact of audit committee existence and audit committee meeting frequency on the external audit: Perceptions of Australian auditors, International Journal of Auditing, vol. 11, no. 1, pp. 51-69, DOI: http://dx.doi.org/10.1111/j.1099-1123.2007. 00356.x.

38. Vafeas, N. and Waegelein, J. (2007), The association between audit committees, compensation incentives, and corporate audit fees, Review of Quantitative Finance and Accounting, vol. 28, no. 3, pp. 241-255, DOI: http://dx.doi.org/10.1007/s11156-006-0012-9.

39. Walt, N. and Ingley, C. (2003), Board dynamics and the influence of professional background, gender and ethnic diversity of directors, Corporate Governance: An International Review, vol. 11, no. 3, pp. 218-234, DOI: http://dx.doi.org/10.1111/ 1467-8683.00320.

40. Watson, W.E., Kumar, K. and Michaelsen, L.K. (1993), Cultural diversity's impact on interaction process and performance: Comparing homogeneous and diverse task groups, Academy of Management Journal, vol. 36, no. 3, pp. 590602, doi: http://dx.doi.org/10.2307/256593.

41. Yatim, P., Kent, P. and Clarkson, P. (2006), Governance structures, ethnicity, and audit fees of Malaysian listed firms, Managerial Auditing Journal, vol. 21, no. 7, pp. 757-782, doi: http://dx.doi.org/10.1108/02686900610680530.

42. Zaman, M., Hudaib, M. and Haniffa, R. (2011), Corporate governance quality, audit fees and nonaudit services fees, Journal of Business Finance and Accounting, vol. 38, no. 1-2, pp. 165-197, doi: http://dx.doi.org/10.1111/j.1468-5957.2010. 02224.x. 